\title{
Aleksandra Ciechomska
}

Uniwersytet Warszawski*

iD https://orcid.org/0000-0003-1621-3441

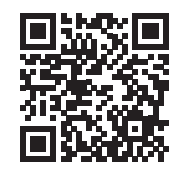

\section{Koncepcja podmiotu kobiecego w ujęciu Ellen Key - wpływ przekładów Ady Werner-Silberstein na modernizację świadomości społecznej}

The Concept of Female Subjectivity with Regard to the Work of Ellen Key the Impact of Ada Werner-Silberstein's Translations on the Modernization of Social Awareness

\begin{abstract}
The article is split into two parts. In the first one the author presents the interpretation of Ellen Key's, the Swedish feminist, works, which were translated by Ada Werner-Silberstein. In the second part the author tries to describe the impact of these texts on Polish feminists at the beginning of the 20th century and the use of Silberstein's translations in the women's press of that time, including the use of Key's language provided by Silberstein. This research perspective allowed the author to extract interesting threads resulting from the translational activity of Ada Werner-Silberstein.
\end{abstract}


* Zakład Poetyki, Teorii Literatury i Metodologii Badań Literackich, Uniwersytet Warszawski ul. Krakowskie Przedmieście 26/28, 00-927 Warszawa

e-mail: ciechomskaaleksandra@gmail.com 
Twórczość naukowa Ady Werner-Silberstein wskazuje przede wszystkim na jej prekursorską rolę w ustanawianiu nowoczesnej, zorientowanej fenomenologicznie estetyki polskiej. Autorka Wstępu do estetyki nowoczesnej jako jedna z pierwszych w Polsce już w 1911 roku wprowadziła bowiem do estetyki wczesną myśl fenomenologiczną — wyłożoną w Badaniach logicznych Edmunda Husserla - oraz uznała postępowanie fenomenologiczne, wychodzące od tego, co dane w bezpośrednim, prerefleksyjnym doświadczaniu, za właściwą metodę badawczą ${ }^{1}$. Nie był to jednak jedyny obszar aktywności badaczki. Drugim polem, na którym intensywnie pracowała, była działalność translatorska.

Silberstein przetłumaczyła między innymi trzy książki szwedzkiej działaczki, Ellen Key. Pojawia się w nich nowa ówcześnie problematyzacja „kwestii kobiecej”, wypracowywany jest także nowy język jej ujęcia, który podważa i redefiniuje dotychczasowy kobiecy dyskurs emancypacyjny. Można wręcz zaryzykować tezę, że przybliżenie koncepcji Key dokonane w Polsce przez Silberstein niejako wpisuje się w aktualne projekty herstoryczne ${ }^{2}$.

Rozprawy Key były częściowo znane w Polsce ${ }^{3}$. Rozpoznania szwedzkiej feministki spotkały się jednak z różnym oddźwiękiem i niejednokrotnie zostały poddane krytyce lub odrzucane (Kuczalska-Reinschmit 1903: 306-307; Jahołowska-Koszutska 1907). Wynikało to, po pierwsze, z niedostatecznego zrozumienia jej myśli, choćby w kwestii macierzyństwa, pomyślanej przez badaczkę jako projekt odtworzenia kobiecej genealogii, a nie jako strategia usytuowania kobiety poza dostępnym mężczyznom porządkiem społecznym, jak błędnie

$1 \quad$ Więcej na ten temat w artykule Kwestia przedmiotu estetycznego a obiektywnośc badań estetycznych. Estetyka Ady Silberstein (Ciechomska 2019).

2 Wyrażeniem tym posługuje się Ewa Kraskowska w artykule: E. Kraskowska, Czy jest możliwa (i potrzebna) herstoria literatury polskiej? [w:] Widnokregi literatury - wielogtosy krytyki. Prace ofiarowane profesor Teresie Walas. Gwoli ścisłości warto przypomnieć, iż herstory jest neologizmem stworzonym przez amerykańską feministkę i dziennikarkę, Robin Morgan. Wywiedziony ze słowa history, interpretowanego jako his-story — opowieść androcentryczną, którą trzeba zastąpić lub chociaż uzupełnić opowieścią ginocentryczną (Kraskowska 2015: 19-32, 23-24).

3 Czytane (i doceniane) między innymi przez Zofię Nałkowską, odwołującą się za pośrednictwem bohaterek swoich powieści do jej samej ówczesnych lektur (Nałkowska 1906: 11). Także w twórczości Gabrieli Zapolskiej, jak ostrożnie zauważa Agata Chałupnik, wiele „[...] sformułowań [...] dowodzi — jeśli nie znajomości pisarstwa Key, to pokrewieństwa myśli" (Chałupnik 2004: 123). 
przekonywały ówczesne feministki ${ }^{4}$. Po drugie, nieprzychylne opinie wynikały z uznania rzekomej niemożności przeniesienia założeń Key na grunt społeczeństwa polskiego, które pod wieloma względami różni się od skandynawskiego. Zarzuty te doprowadziły do uproszczenia postulowanego przez nią uwzględnienia różnicy płciowej. Zawężenie tej różnicy do różnicy biologicznej pociągnęło za sobą zignorowanie wpisanego w koncepcję badaczki modelu kobiecej podmiotowości, a co najmniej sprowadzenie jej koncepcji wyłącznie do postulatu, wyznaczającego kobiecie zadanie doświadczenia macierzyństwa ${ }^{5}$.

Pisma Key wymagają więc w pierwszej kolejności uważnej lektury, by wnikliwiej odczytać to, co w znacznej mierze zostało pominięte przez ówczesnych czytelników (częściej czytelniczki) tych prac, a przy okazji - przypomnieć mało dziś znaną myśl szwedzkiej działaczki, która w centrum rozważań umieściła ucieleśnioną (i nieredukowalną) naturę kobiety. Pozwoli to przejść do zinterpretowania marginalizowanych w Polsce na przełomie XIX i XX wieku poglądów na dowartościowanie różnicy płciowej. To z kolei wesprze wizerunek Silberstein jako kobiety myślicielki, zaangażowanej w próby zmiany świadomości społecznej.

\section{Podmiot kobiecy w ujęciu Ellen Key (dowartościowanie różnicy płciowej oraz koncepcja „macierzyństwa społecznego”)}

Obraz kobiety, jaki rysuje się z poglądów Key, nie odnosi się do emancypacji, w której orzeka się o konieczności upodobnienia kobiety do mężczyzny, lecz do wykorzystania, a wręcz wyeksponowania kobiecej perspektywy, wynikającej ze specyfiki płci. Key krytycznie ustosunkowuje się do przeświadczenia o wyższości mężczyzny nad kobietą, ale i jedocześnie do podejmowanych przez ruch kobiecy prób zrównania kobiet i mężczyzn:

Zarówno ruch emancypacyjny ze swojem ${ }^{6}$ dążeniem do równouprawnienia kobiety z mężczyzną $\mathrm{w}$ wychowaniu i pracy, w życiu rodzinnem i obywatelskiem, jakoteż reakcya nowa i stara konserwatywna - ze swem przeświadczeniem, że współzawodnictwo w pracy z mężczyzną pozbawia kobietę kobiecości - nie obejmowały dotychczas dostatecznie kwestyi kobiecej jako całości. Jednostronność, bez względu na to, czy wyraża się jako krańcowa dążność do uprawnienia, czy też jako krańcowa dążność do rozdziału, może niekiedy mieć duże znaczenie [...]. Ale stale nie chroni indywidualności kobiecej, tylko ją w dalszym ciągu uogólnia [...]. (Key 1905a: 120)

Key, mimo docenienia działalności skandynawskiego ruchu kobiecego, wychodzi z założenia, że dotychczasowe poglądy na kwestię kobiecą nie pozwoliły dostatecznie określić indywidualności kobiet. Jak twierdzi, zrównanie obu płci, które postulowały feministki, prowadzi do zatarcia tego, co odróżnia kobietę i mężczyznę, a co za tym idzie - do niedostrzeżenia zdolności i potencjału kobiet, uruchamiających w rezultacie jedynie męskie zasoby swoich możliwości i lokujących wyniki swojej pracy w dziedzinach dotąd zajmowanych tylko przez mężczyzn. „Jednakże właśnie te pomyślne wyniki zasłaniały coraz bardziej przed oczami

4 Zofia Seidlerowa przestrzegała np. na łamach „Bluszczu”, że koncepcje Key stanowią niedorzeczny i niebezpieczny prąd w ruchu kobiecym (Seidlerowa 1906: 2).

5 Mówiąc ogólnie, w działalności emancypacyjnej kobiet początku XX stulecia wyłoniły się dwa punkty widzenia, a z polemicznego starcia ich zwolenników powstały dwie, wykluczające się strategie emancypacyjne: zrównania kobiet i mężczyzn oraz podkreślenia ich odrębności. By ująć tę alternatywę w terminach feminizmu lat 70., już wtedy doszło do podziału na feminizm egalitarny i feminizm różnicy.

6 Pozostawiono oryginalny zapis ortograficzny i interpunkcyjny w cytowanych fragmentach — bez modernizacji. 
kobiet fakt, iż ich najcenniejsze uzdolnienia nie zostały przy tym bynajmniej spożytkowane" (Key 1905b: 5) - czytamy. Poprzez współzawodnictwo, które takie przekonania wywoływało, kobiety odrzucają, zdaniem Key, siły kobiecej natury, co prowadzi do naśladowania znanych już (męskich) dokonań, szerzej zaś do jeszcze większej męskiej dominacji w obowiązujących wówczas modelach myślenia o relacjach płciowych. Eksplorując bowiem męskie siły, kobiety przyczyniają się do dalszego wykluczenia z systemów społecznych, politycznych, ekonomicznych i rodzinnych. W efekcie kobieta będzie jedynie reprodukować męskie wzorce, przy jednoczesnym nierozpoznaniu, stłumieniu, a nawet blokadzie i wyparciu oraz rozproszeniu własnej tożsamości.

Nie chodzi jednak o to, by postawić na różnicę płciową, która rozgraniczała to, co określane jako męskie bądź kobiece, ale by — nie wychodząc poza te porządki, a przepracowując je - umożliwić rozwój przynależnych płciom możliwości. Należy zauważyć, że Key wyraźnie opowiada się za tym, iż płeć nie jest jedna i nie jest jednością:

Jestem osobiście głęboką przekonaną, że między naturą kobiety a mężczyzny istnieją stanowcze różnice, którym bynajmniej nie przeczy fakt, że zdarzają się kobiety z umysłem męskim, a mężczyźni z umysłem kobiecym, ani też, że jest wzajemnie oddziaływanie, dzięki któremu mężczyzna do pewnego stopnia przyswaja sobie charakterystyczne cechy kobiety, a ona męskich właściwości nabiera. Rzecznicy emancypacji słusznie wskazywali ten stan rzeczy, jako argument przemawiający za wyzwoleniem. Jednocześnie jednak zaniedbali skierowania sił kobiecych na właściwe im dziedziny, ponieważ celem ruchu kobiecego było przedewszystkim udowodnić równość obu płci i zrównania ich praw się domagać. (Key 1905a: 5-6)

W innym miejscu powiada: „zresztą, nie można tu mówić o mężczyźnie wogóle i o kobiecie wogóle, bo obie płcie są dziś bardzo zróżnicowane [...]” (Key 1905c: 261).

Co ważne, przekonanie to nie skupia się wyłącznie na zagadnieniach podmiotowości, płciowości czy seksualności, ale wychodzi poza te problemy i odnosi się również do społecznych sfer życia. W swojej koncepcji różnicy Key dostrzega szansę na przeformułowanie ówczesnego modelu zawodowego funkcjonowania kobiet. Rzecz w tym, by wybierały one profesje, w których ich umiejętności i zdolności znajdą realizację czy, jak powiedziałaby Key - by spełniały się społecznie w dziedzinach zgodnych z kobiecą naturą, poza męskim polem pracy: „[...] ich [tj. kobiet - A.C.] wybitna indywidualność, ich żywe uczucia społeczne, ich wyższe wykształcenie i rozszerzony widnokrąg umysłowy mają cel wyższy, niż osiągnięcie równouprawnienia z mężczyzną tam, gdzie natura sama go lepiej uzbroiła [...]" (Key 1905b: 41) - czytamy. Stanowisko autorki Indywidualności wykracza więc poza dominujący na początku XX wieku, tradycyjny sposób pojmowania różnic między kobietami i mężczyznami zarówno w aspekcie biologicznym, jak i społeczno-kulturowym ${ }^{7}$. Natomiast wszelkie praktyki neutralizowania różnicy płciowej przyczyniają się, zdaniem Key, jedynie do podtrzymania nierówności.

Szwedzka działaczka wielokrotnie podkreślała, że jej poglądy nie odnoszą się do kobiet z najniższej klasy społecznej, których wybory zawodowe podyktowane są sytuacją materialną zmuszającą je do podjęcia jakiejkolwiek pracy, ale do kobiet mogących dowolnie, bez względu na czynniki ekonomiczne, kształtować swoje życie zawodowe. Niemniej zaznaczała przy tym, że nie należy lekceważyć potrzeb kobiet uboższych pozbawionych sposobności do samodzielnej walki o rozwój i zarzucała ruchowi kobiecemu ignorowanie ich sytuacji oraz działanie wyłącznie na rzecz kobiet $\mathrm{z}$ wyższych klas społecznych. 
Model myślenia Key o relacjach płciowych sprowadza się do afirmacji niewyczerpywalnego potencjału twórczego natury. Nie oznacza to jednak, że mowa o esencjalizacji kobiecości wedle ówczesnego pojmowania, to jest o uprzedmiotowieniu kobiety w stosunku do uprzywilejowanego podmiotowego pierwiastka męskiego ${ }^{8}$. Trafniejszym sformułowaniem, lepiej oddającym myśl autorki Indywidualności, wydaje się: „kobiecość ucieleśniona”. Mówienie o kobiecości w ujęciu badaczki nigdy nie zostaje bowiem oderwane od kobiet i ich doświadczeń, a jednocześnie jest skupione na ciągłym kształtowaniu przez nie swojej egzystencji społecznej:

[...] jako pierwsze i ostatnie rozwiązanie kwestji kobiecej, musimy żądać, by najwyższą ambicją kobiety stało się pozostać tym, czym jest, [...] czym ją natura stworzyła! [...] i stąd wywnioskować, w jakiej dziedzinie posiada ona najwięcej widoków podniesienia swego znaczenia dla kultury, gdy właściwe jej siły wyswobodzą się i rozwiną. (Key 1905b: 97)

Key, choć kładzie nacisk na problem kobiecej natury, nie koncentruje się na tym, co określałoby jej istotę, nie tematyzuje i nie definiuje tego, czym jest (a tym bardziej być powinna) kobieta i kobiecość 9 . Proponuje natomiast koncepcję, która odnosi się do twórczej, autopojetycznej sposobności kobiety, której źródłem i rezerwuarem jest kobieca cielesność, a także ściśle wiąże to z zagadnieniem macierzyństwa, tak mocno uwzględnionego potem w Irigariańskiej filozofii ${ }^{10}$. W ujęciu szwedzkiej działaczki to macierzyństwo stanowi punkt wyjścia do rozważań o możliwościach rozwoju myśli emancypacyjnej, szerzej zaś — o konieczności otwarcia

8 Mówiąc o esencjalizmie w odniesieniu do myśli Key, mam na myśli definicję zaproponowaną przez Dianę Fuss [wszystkie tłum. $\mathrm{z}$ ang. własne]:

Esencjalizm jest tradycyjnie definiowany jako wiara w prawdziwą esencję — która jest nieredukowalna, niezmienna i dlatego konstytutywna dla danej osoby i rzeczy. Definicja ta przedstawia Arystotelesowskie rozumienie esencji [...]. W teorii feministycznej esencjalizm wyrażany jest na różne sposoby i odnosi się do wielu możliwych założeń. Najczęstszym z nich jest lokowanie esencjalizmu w odniesieniu do czystej lub źródłowej kobiecości, kobiecej esencji, istniejącej poza granicami porządku społecznego i tym samym nieskażonej (lub zwyczajnie wypartej) przez porządek patriarchalny. Esencjalizm może być również odczytywany w odniesieniu do uniwersalnej kobiecej opresji, jako założenie istnienia totalizującego systemu symboli, który zniewala wszystkie kobiety na przestrzeni historii i w kontekście różnych kultur. (Fuss 1989: 2)

9 Zdaniem Anety Górnickiej-Boratyńskiej późniejsze teorie mówiące o specyfice kobiecego doświadczenia wywodzą się, z widocznej w myśleniu kobiet w pierwszej połowie XX wieku, perspektywy dyferencjalistycznej, zakładającej istnienie nieredukowalnej różnicy płci (Górnicka-Boratyńska 1918). Badaczka wprawdzie nietrafnie uznaje każdą z rozważanych koncepcji (Julii Kristevej, Hélène Cixous i Luce Irigaray), tak różnych pod względem paradygmatycznym i kulturowym, za reprezentatywną dla écriture féminine oraz, również nieprecyzyjnie, określa je jako esencjalistyczne. Niemniej należy zgodzić się z jej rozpoznaniem, że formująca się wcześniej tradycja dyferencjalistyczna, w którą wpisują się założenia Key, stanowi dla nich układ odniesienia („kobiecego pisania siebie” i „mówienia jako kobieta”). W obu przypadkach dwoistość, biseksualność, ulokowana wewnątrz podmiotu, pozwala na „[...] odkrycie w sobie, w każdym z osobna, obecności różnorodnie manifestujących się i krystalizujących w pojedynczym podmiocie, dwóch płci [...]" (Cixous 1993: 156). Kobiecość wiąże się tu więc nie tyle z ciałem kobiety, ile „[...] staje się synonimem różnicy pomyślanej poza dominacją jednej płci nad drugą" (Szopa 2017: 35).

10 Projekt parler femme, mimo że zakorzeniony w innej sytuacji społeczno-politycznej, podobnie jak myśl Key stawia opór narracji właściwej dla kultury patriarchalnej. Buduje feminizm na pojęciu różnicy płci. Irigaray przedstawia kobiecą płciowość w kategoriach pełni, a nie braku, szerzej zaś - sprzeciwia się mitotwórczym trybom orzekania, skoncentrowanym wokół jednopłciowości, o których właśnie pisze Key, i zwraca uwagę na potrzebę odnalezienia przez kobietę własnej tożsamości poza dominującymi mitami patriarchalnej proweniencji, czasem wbrew wprowadzanym przez te mity dystynkcjom i hierarchiom, czasem splatając i krzyżując fundowane przez nie podziały i rozróżnienia. 
feministycznych dyskursów na dwukierunkową relacyjność: między wszystkimi kobietami oraz między kobietami a mężczyznami. Stawiając pytanie o właściwą drogę emancypacji, myślicielka wychodzi od zagadnienia macierzyństwa, stanowiącego, jak wyjaśnia, twórczą siłę kobiety i jej wkład w kulturę: „Od tysięcy lat rozwinięta, skoncentrowana i spożytkowana siła wytwórcza kobiety służyła rozwojowi kobiety" (Key 1905b: 19), pisze w stylu przypominającym ujęcia marksistowskie. W przekonaniu Key rzecz nie w usytuowaniu kobiety w zależności od dokonanych przez nią wyborów między naturą a kulturą, ale w tym, by miejsce kobiety w społeczeństwie i kulturze zawsze miało swój początek w naturze, powołującej ją do macierzyństwa.

Co ważne, powracającym tematem jest fizyczna i psychiczna odmienność kobiety, jak w poprzednich rozprawach, uznana przez Key za kluczową. Ponownie podkreślając różnicę płciową, badaczka wyjaśnia, iż dzięki swojej fizjologii kobieta predysponowana jest do rodzenia i wychowania dzieci, mężczyzna zaś nie posiada do tego dyspozycji. Macierzyństwo jest zatem kobiecie naturalnie przypisane, stanowi jej główne zadanie, natomiast wszelkie inne działania od niej wymagane i stawiane na pierwszym miejscu, są — według Key — w nią wymierzone, uniemożliwiając jej samorealizację: ,jeżeliby miała [praca - A.C.] dojść do pierwszorzędnej wartości, musiałaby zająć w życiu kobiety to samo miejsce, co w życiu mężczyzny. W takim razie wyniknąćby stąd musiało stopniowe, fizyczne i psychiczne, przeobrażenie żeńskiego typu" (Key 1905b: 35). Niemożliwe jest bowiem, jak twierdzi badaczka, pełne zaangażowanie w dwie lub więcej dziedzin, jeśli zakłada się sumienne wypełnianie obowiązków. A ponieważ w pierwszej kolejności kobieta jest matką, to nie należy od niej żądać pełnego oddania się pracy intelektualnej bądź naukowej.

Choć Key (czasem mniej, czasem bardziej przekonująco) dowodzi celności swojej argumentacji, dla ówczesnych feministek okazała się ona nie do przyjęcia. Jednakże przytoczony krytyczny komentarz raczej potwierdza tezy szwedzkiej badaczki, która próbowała uświadomić kobietom, jak niewiele z nich potrafi pogodzić pracę zawodową z macierzyństwem. Wysunięte zarzuty uznania kobiet za gorsze, mniej inteligentne od mężczyzn, pozbawione właściwości, które mogłyby je predestynować do pełnienia określonych aktywności zawodowych, ale też np. naukowych, wskazują na to, że jej czytelniczki rozminęly się z wywodami. Key pisze bowiem wyraźnie:

Olbrzymią kulturalną pracę kobiety stanowi zhumanizowanie tej całej sfery życia, na którą składają się warunki trwania rodzaju ludzkiego. Nie można też żadną miarą powiedzieć, że kobieta jest młodszym, tj. późniejszym czynnikiem kulturalnego rozwoju, przeciwnie jest ona starszym. (Key 1905b: 18)

Wbrew temu, co można odczytać z komentarzy kwestionujących podejście autorki Trwonienia sit kobiecych, rezerwuje ona dla kobiet pozycję wyższą nawet niż dla mężczyzn i niejako próbuje im ją przywrócić, odwołując się właśnie do macierzyństwa niezbywalnie uwikłanego w kwestię kobiecą, ale jednocześnie znikającego z pola widzenia ówczesnych feministek. Namysł nad wypowiedziami szwedzkiej działaczki skłania do stwierdzenia, że pozostaje ona zwolenniczką tradycyjnego modelu rodziny, wyraźnie jednak sprzeciwia się wizji małżeństwa, które miałoby charakter wyłącznie instytucjonalny i nie było oparte na uczuciach. Dlatego też broni prawa do macierzyństwa kobiet niezamężnych. Jak powiada: „tą drogą dojdzie się wreszcie do tego, że każda subtelnie czująca kobieta macierzyństwo swoje zawdzięczać będzie tylko wzajemnej miłości”; że macierzyństwo to, instynkt macierzyński, należy 
uznać, jak wyjaśnia, za nadrzędny względem małżeństwa, ponieważ „[...] w stosunku matki do dziecka - tkwi również źródło tych wszystkich czynników, które kształtowały sympatyczne, altruistyczne popędy ludzkości, potęgując je i rozszerzając ich zakres” (1905b: 17). I tak dzięki uczuciom macierzyńskim kształtują się związki międzyludzkie, w tym rodzinne, bowiem „[... w stosunkach osobistych typowej kobiety do najwyższego dochodzi naprężenia w sferze, stanowiącej zarazem jej najwyższy cel życiowy: w macierzyństwie przez miłość" (Key 1905b: 10).

Motywacja stojąca za podjęciem przez Key tematu różnicy płciowej, podobnie jak całej problematyki macierzyństwa i emancypacji, wykracza poza jednostkowe doświadczenia poszczególnych kobiet. „Zupełnie słusznie nazwano mój indywidualizm indywidualizmem społecznym” (Key 1905c: 11) — pisała badaczka, wyraźnie świadoma oksymoronu. Sądy, które formułowała, rzeczywiście miały pełnić funkcję społeczną, a celem podkreślania biologicznej różnicy między płciami było wyeksponowanie konieczności współpracy kobiet i mężczyzn, stanowiącej warunek niekolizyjnego funkcjonowania zbiorowości. Według Key stanowiska zajmowane przez współczesne jej feministki, po pierwsze, uniemożliwiają bowiem indywidualną ekspresję, po drugie zaś prowadzą do działań przeciw społeczeństwu. Ostatecznie „kwestya kobieca” okazuje się dla Key nie tylko kwestią zdefiniowania podmiotowości kobiet i ich indywidualnej ekspresji, lecz również (a może przede wszystkim) kwestią społeczną, w której centrum znalazło się zagadnienie macierzyństwa. Także macierzyństwo, rozpatrywane w kontekście funkcjonowania zinstytucjonalizowanej zbiorowości, nazwała — podobnie jak „indywidualizm” — oksymoronicznie: „macierzyństwem społecznym”.

Koncepcja Key stanowiła więc atrakcyjną w swoim czasie propozycję, w której może się odnaleźć współczesna myśl feministyczna. Swoje założenia Key niejednokrotnie powtarzała w różnych pracach; wyartykułowana raz myśl powracała w innym miejscu. Choć nie wypracowała spójnej, jednolitej koncepcji, wyznaczyła pewien - ówcześnie oryginalny - kierunek myślenia i ożywczą propozycję, akcentującą potrzebę zmian mentalnych i społecznych. Jej rozumowanie, zarówno na temat różnicy płciowej, jak i macierzyństwa społecznego, zasadzało się przede wszystkim na nierozłącznym pojmowaniu natury i kultury oraz określeniu podmiotu jako jednostki zróżnicowanej płciowo, będącej jednocześnie niezbywalną częścią społeczeństwa.

Key unika bowiem myślenia dualistycznego, łącząc to, co biologiczne, i to, co kulturowe, jednostkowe i społeczne, materialne i dyskursywne. Niewątpliwie sytuuje to jej myśl obok koncepcji Irigaray, zgodnie z którą w każdym akcie wypowiedzi zawiera się dwoistość sposobu artykulacji ${ }^{11}$. Dziewiętnastowieczne sprowadzenie pojęć kobiety i mężczyzny do opozycji natura-kultura, rządzącej ówczesnym pojmowaniem świata społecznego i intelektualnego, stało się przyczyną przyjęcia przez kobiety stanowiska emancypacji od kobiecości, czyli odejścia od natury, uznanego za warunek usytuowania się po stronie kultury. Natomiast

11 Irigaray lokuje kobiecą wypowiedź nie tylko wewnątrz, ale i na zewnątrz mówiącego podmiotu, toteż uwzględnia wszelkie sposoby artykulacji, także niejęzykowe, określając je „mówieniem jako kobieta”. Parler femme jest takim trybem wypowiadania się, który umożliwia uwolnienie się od znaczeń narzuconych przez porządek fallogocentryczny i mówienie zgodnie ze specyfiką swojej płci. Mówienie to należy rozumieć zarówno jako cielesny, jak i dyskursywny sposób kształtowania podmiotowości, nieograniczający się do uznawania wyłącznie jednej kobiecości wedle jakiegokolwiek określonego wzorca.

Irigaray podkreśla tym samym, że akt wypowiedzi nie jest wyabstrahowanym z porządku relacji społecznych sposobem odtwarzania abstrakcyjnych znaków pojęciowych, lecz tym, co zakorzenione w cielesności [...] a co dąży do wyrażenia przez rozmaite [...] działania kulturowe. (Szopa 2018: 146) 
według szwedzkiej działaczki, jak wynika z przeprowadzonych wcześniej rozważań, rzecz nie w zniesieniu różnicy płciowej, lecz w stworzeniu nowej praktyki emancypacji do kobiecości, a tym samym wypracowaniu nowego pojęcia natury, osadzonego w cielesności, ale nie waloryzowanego negatywnie jako niezbędny (oraz pasywny) człon-korelat w binarnej opozycji natura-kultura. Nie sposób jednak pominąć, że zwrot do cielesności nieuchronnie zbliża myśl Key do określonej modalności esencjalizmu, który zakłada istnienie istoty kobiecości. Z kolei założenie, że pojęcie kobiety odnosi się do swego rodzaju wspólnej tożsamości, prowadzi do zniwelowania wszelkich różnic między podmiotami kobiecymi: rasowych, etnicznych, społecznych, seksualnych, wiekowych i innych, które autorka Trwonienia sit kobiecych nazwałaby indywidualnymi, czyli określającymi podmiotowość. Tym sposobem rozumienie kobiecej natury ponownie popada w określone schematy myślenia. Choć są one odległe od maskulinistycznego pojmowania kobiecości, wydają się również neutralizować kobiecą podmiotowość.

Niezależnie od tych przesunięć ku esencjalizmowi — wtedy nienagannemu i bodaj czy w ogóle uświadamianemu - w myśleniu Key chodziło przede wszystkim o konceptualizację kobiety bez znoszenia kobiecości, bez emancypowania się od niej i umiejscawiania kobiety na równi z mężczyzną po stronie kultury, oraz o znalezienie alternatywnego ujęcia natury i cielesności, w którym ciało nie byłoby ani bierną materią, kształtowaną przez mężczyzn, ani „ciałem w ogóle” (Butler 2008) będącym jedynie abstrakcyjną i uniwersalną ideą kobiecego ciała. Konceptualizacja natury polegałaby tu na — powtórzmy - aktywnym stawaniu się, w którym pojęcie kobiety, bez względu na podział natura-kultura, jest ruchomym znaczącym, obejmującym wszystkie jednostki przez nie reprezentowane. Ukonstytuowanie podmiotu (określanego, przypomnijmy, jako indywidualny) następuje dzięki zakorzenieniu go w przestrzeni społecznej, osadzonej w cielesności jednostki. Ten porządek jest dla Key oczywisty: podmiotowość kształtuje się, „[...] dzięki tym, którzy z dzieci natury stali się istotami uspołecznionemi, a z tych dopiero indywidualnościami” (Key 1904: 26).

Stanowisko Key wydaje się bliskie koncepcji Karen Barad, której zdaniem właściwym sposobem wykazania różnicy płciowej, a raczej stawania się tej różnicy, jest ujmowanie jej nie w kontekście ekspresji biologicznej lub założeń społeczno-kulturowych, lecz w odniesieniu do obu tych kwestii, współkonstytutywnych względem siebie (Barad 2007; 2012: 323-360). Badaczka przyjmuje, że znaczenie nie występuje wyłącznie w dyskursie lub materii, ale we współzależności świata naturalnego i społecznego ${ }^{12}$. Prace Barad, jak większości badaczek i badaczy z zakresu nowego materializmu feministycznego, mają charakter transdyscyplinarny. Badaczka łączy teorię feministyczną z teorią fizyki kwantowej oraz ze studiami nad technologią i filozofią. Dla niniejszych rozważań ważne jest, że za punkt wyjścia swoich rozważań Barad bierze nieredukowalną zależność między naturą i kulturą ${ }^{13}$, kluczową dla założeń Key, choć inaczej omawianą przez amerykańską filozof i niekiedy osadzoną w innym kontekście interpretacyjnym. Myśl autorki Indywidualności, zgodnie z którą ekspresja kobiecej natury

12 Prócz pojęcia mattering, oznaczającego proces formowania się podmiotu właśnie w relacji materii i dyskursu, Barad wyróżnia jeszcze pojęcia: knowing in being i becoming. Pierwsze z nich określa jako poznanie poprzez ciało posiadające płeć i przez płeć rozumiane. Z kolei becoming jest rozumiane jako właściwość podmiotu nastawionego na ciągłe „stawanie się," gdzie tożsamości splatają się w warstwie cielesnej i językowej.

Barad korzysta z zaproponowanego przez Donnę Haraway pojęcia naturokultury, które wskazuje na relacyjny charakter natury i kultury. W ramach tej logiki Haraway proponuje odrzucić klasyczny podział natura-kultura (stanowiący zawłaszczenie natury przez kulturę) na rzecz przepracowania dychotomii podmiot-przedmiot i przyznania przedmiotom, czyli materii i naturze, statusu sprawstwa. 
dotyczy także kwestii społecznej, znajduje bowiem niejako wsparcie w tym rozumowaniu. Koncepcje Key i Barad lączy przeświadczenie o wzajemnym oddziaływaniu natury i kultury. U pierwszej z badaczek wyłania się z niego określona koncepcja podmiotu, w którym, według Barad, „posiadanie wiedzy [knowing] jest bezpośrednim [...] zaangażowaniem [...]. Nie ma wiedzy zdystansowanej. Zamiast oddzielenia podmiotu i przedmiotu istnieje ich splątanie" (Dolphjin i Van der Tuin 2018: 44).

Właśnie ten kierunek myślenia (choć nieoczywisty przy pobieżnej lekturze prac szwedzkiej działaczki) zdawała się dostrzegać u Key Ada Silberstein. Stawia to przed koniecznością nie tylko problematyzacji przekładów dokonanych przez autorkę Wstępu do estetyki nowoczesnej, lecz także rozpatrywania prac Key jako jednego ze źródeł inspiracji jej światopoglądu naukowego.

Z tego punktu widzenia znaczące są słowa Silberstein, odwołujące się do Potrzeb życia, mimo że umieszczone tylko w przypisie, który zwykle jest zaniedbywany w trybie pospiesznej, nieuważnej lektury. Badaczka zapisuje w nim: „Ellen Key powiada, że » wykształceniem jest to, co się nam pozostaje, skoro zapominamy wszystkiego, czegośmy się nauczyli «. Te słowa oddają doskonale, w formie paradoksalnej, myśl naszą" (Werner-Silberstein 1911: 44). Przytoczona wypowiedź stanowi komentarz do rozważań Silberstein o wiedzy estetycznej, która, jak twierdzi autorka $W$ stępu do estetyki nowoczesnej, nakłada się na wrażenie estetyczne:
[...] wiedza estetyczna — równie jak wszelka inna — którą pierwotnie zdobywamy z wysiłkiem umysłu i która w pierwszym okresie utrzymuje się w polu świadomości, z czasem stanowi tylko materjał asocjacyjny, który dzięki umyślnie nań skierowanej uwadze, albo przy okazji do repro- dukcji, wstąpić może znów w pole świadomości [...] może ona [wiedza - A.C.] pogłębiać i wy- subtelniać nasze rozkosze, nie ujmując naszej reakcji nic a nic z jej bezpośredniości; ale wiedza owa musi nas przeniknąć, nie zaś igrać na powierzchni [...]. (Werner-Silberstein 1911: 44)

Oryginalność koncepcji estetyki nowoczesnej Silberstein polega na zespoleniu dwóch podejść: podmiotowego i przedmiotowego. Ta dwoista podmiotowo-przedmiotowa specyfika doświadczenia i poznania estetycznego decyduje z kolei o wyodrębnieniu przedmiotu estetyki. Co jednak istotne, postawa estetyczna widza, która jest niezbędna do uchwycenia i rozpoznania obiektywnej wartości estetyczne, a co za tym idzie — przeżycia estetycznego, zależy, zdaniem Silberstein, od wielu czynników. Komponentami tego przeżycia są między innymi stopień i typ rozwoju reakcji estetycznej widza, jego preferencje, obycie i kompetencje. Badaczka bierze także pod uwagę, a nawet wyróżnia uwarunkowania fizjologiczne, decydujące o typowości reakcji postrzegającego podmiotu, i jego indywidualne skłonności psychologiczne. „Na typ zachowania estetycznego składa się wiele warunków [...]. Przedewszystkiem weźmy pod uwagę, jak rożna jest już sama wrażliwość zmysłów u różnych indywidów, [...] grających największą rolę w ujmowaniu estetycznem" (Werner-Silberstein 1911: 19) — czytamy. W innym miejscu Silberstein pisze zaś:

Mówiąc zaś o typach pod względem odnoszenia się do piękna, myślimy przez to, że istnieje więcej, niż jeden sposób napawania się pięknem, już to dzięki temu, że różni widzowie zatrzymują się na różnych charakterach piękna, złożonych w jednym i tym samym przedmiocie, np. w krajobrazie jedni na kolorycie, drudzy znów na nastroju, już to, że jeden i ten sam charakter różni wodzowie biorą. Tutaj zaś rozróżniamy dwa typy, zgruba biorąc: intelektualny i emocjonalny, ten bardziej odczuwa, tamten bardziej pojmuje. (Werner-Silberstein 1911:22) 
Tym samym badaczka podkreśla złożoność subiektywnego ${ }^{14}$ spostrzeżenia widza. Takie ujęcie podmiotowości niewątpliwie wyłania się z myśli Key, która w Nowych szkicach pisze następująco o odczuwaniu piękna:

Wiadomo mianowicie, że oprócz odczuwania piękna potrzeba jeszcze wielu innych czynników [...]. Dopóki jednak nie dodamy, że rodzaje, wartości i uzewnętrznienia uczucia piękna zależne są od przyrody, wrażeń życiowych i wpływów czasu, dopóty będzie trwał spór o moralne oddziaływanie piękna. (Key 1905a: 51)

Nie idzie tu już o podmiot kobiecy (choć podmiot w ujęciu Key zawsze jest upłciowiony), ale o podmiot, który, po pierwsze (jak wynika z wcześniejszych wniosków), jest rozpatrywany w relacji do świata zewnętrznego. Po drugie - u którego poszczególne wrażenia określają rozmaite czynniki, uwarunkowane, zdaniem Silberstein, przez typ i stopień zdolności przeżywania estetycznego ${ }^{15}$. W tym punkcie rozważań obie badaczki tematyzują podobny splot problemów dotyczący pojmowania piękna i kluczowej zarówno dla poglądów feministycznych Key, jak i fenomenologicznych Silberstein, aktywności podmiotu. Ich podejścia korespondują ze sobą. Znajomość myśli szwedzkiej działaczki niewątpliwie wpłynęła na sposób rozumowania Silberstein przed jego ostatecznym ukształtowaniem dzięki rozprawom najbardziej dla niej autorytatywnego Husserla. W rezultacie tych ustaleń tym ważniejsza wydaje się kwestia translatorskiej działalności autorki Wstępu do estetyki nowoczesnej.

\section{Obieg społeczny koncepcji Key w przekładach Silberstein ${ }^{16}$}

W posłowiu do Kobjety Silberstein stwierdza:

Są „książki” z którymi niepodobna się rozstać! [...] Pod tem wrażeniem powzięłam też myśl przekładu „Szkiców” Ellen Key, głośnej dziś autorki szwedzkiej. Najbardziej palące kwestje, jakie niepokoją dziś umysłu i serca, znalazły u niej swój wyraz - i jaki wyraz! Z taką siłą, z taką pewnością zwycięztwa, z takiem proroczem natchnieniem mało kto dziś mówi. (Key 1903:5)

Zdaniem Sherry Simon przekłady stanowiły ważną część ruchów społecznych, w których uczestniczyły kobiety. „Feminizm pierwszej fali był ściśle związany z tym ruchem. Kobiece tłumaczenia przekładały się na budowanie sieci komunikacyjnych w służbie postępowych programów politycznych [...]" (Simon 1996: 2) - czytamy. Niezwykle istotne wówczas przekłady, które wyszły spod pióra kobiet, miały na celu nie dopuszczać do stabilizacji lekturowych sensów, a co za tym - znieść przewagę przekonań, zgodnie z którymi kobiety nie były widoczne zarówno w języku, jak i społeczeństwie ${ }^{17}$. W swoich rozważaniach Simon

14 Warto przy tym wspomnieć, że niejednokrotnie Silberstein określa je „indywidualnym”, choćby w tym miejscu: "Otóż, tu właśnie otwiera się jakoby pole dla nieograniczonej »dowolności« zachowania się widza estetycznego, czyli dla »indywidualności«, dla »subjektywności« [...]" (Werner-Silberstein 1911: 16).

Ten sposób myślenia Key potwierdza także inny cytat (choć w tej wypowiedzi, w odróżnieniu od wcześniej przytoczonych słów, Key kładzie większy nacisk na odbiór piękna ze względu na wrażenia wywołane danym dziełem niż niezależnych od nich uwarunkowań widza):

Ale gdy dziełom tym brak warunków do takiego poruszenia duszy, albo łączników pomiędzy wyobraźnią a uczuciem a różnemi innemi zdolnościami duchowemi, [...] wówczas przyjemność sprawia tylko doskonała technika kucia i ornamentyki [...]. (Key 1905a: 54)

Co ważne, Simon choć wypowiada się wyłącznie na temat przekładów feministycznych, którymi zajmowały się kobiety, podkreśla, iż teoria przekładu feministycznego dotyczy także mężczyzn. Jak wyjaśnia badaczka, 
porusza między innymi kwestie walki z niewolnictwem oraz ruchów na rzecz walki o prawa obywatelskie i polityczne kobiet w okresie od XVIII do XX wieku. Douglas Robinson wskazuje natomiast, że już w XVI wieku pojawiają się początki tego, co określa jako „feminizację" (feminization) przekładu, czyli procesu, w którym kobiety zaczynają tłumaczyć, by zabrać głos w społeczeństwie (Robinson 1995: 153-175). Zwłaszcza w Anglii był to jeden z niewielu sposobów na ujawnienie aktywności intelektualnej kobiet. Działalność translatorska służyła do wyrażenia sprzeciwu wobec społecznych i ideowych hierarchii, przyznających mężczyznom uprzywilejowaną pozycję, oraz częściowego uwolnienia się od normatywnych uwarunkowań kultury patriarchalnej.

W Polsce do pierwszych dziesięcioleci XX wieku był to protest niemy. Jego bezgłośność diagnozuje Ewa Rajewska:

[...] „pewien prestiż” zawodowy na początku wieku przysługiwał jednak raczej tłumaczowi, z tłumaczką sprawa była bardziej skomplikowana. W miarę jak w dziedzinie tłumaczeń literackich - analogicznie do procesów zachodzących w całej literaturze polskiej — piór niewieścich przybywało, obok rzeczownika męskoosobowego „tłumacz”, obejmującego i przekładowców, i przekładowczynie, coraz częściej zaczęła pojawiać się „tłumaczka”, określenie jednak niesymetryczne, któremu przynajmniej przez pierwsze dekady wieku XX brakowało części tego skromnego poważania, jakim cieszył się jego męski odpowiednik [...]. Gremialnie ganione przez luminarzy literatury i przekładu swego czasu, nie czując się pełnoprawnymi uczestniczkami życia literackiego [...], thumaczki przełomu stuleci i pierwszych dekad wieku dwudziestego nierzadko wolały pozostać w cieniu. Nie tylko cieniu swojej autorki czy swego autora, zgodnie z miejscem wyznaczonym tłumaczom przez ówczesną koncepcję przekładu — ale w cieniu podwójnym: np. męskiego pseudonimu [...]. (Rajewska 2015: 269-270)

Badaczka zwraca uwagę na liczne prace tłumaczek, które w tamtym czasie rezygnowały z podpisywania się własnym nazwiskiem, by uniknąć wskazania na swoją płeć, a co jeszcze istotniejsze - używały męskich pseudonimów (jak Zofia Mańkowska publikująca jako Adam M-ski). Przyjęcie pseudonimu mogło mieć także na celu wydzielenie i odgraniczenie tej części działalności autorki, która niekoniecznie chciała być identyfikowana z ideami i światopoglądem przekładanego utworu. Tłumaczenia bywały bowiem „znaczącym uzupełnieniem twórczości oryginalnej. Podjętych z fascynacji autorem i/lub dziełem, wypełniających lukę w polskim piśmiennictwie, a przy tym dodających prestiżu własnemu literackiemu portfolio inicjatyw nie brakowało" 18 (Rajewska 2015: 276).

Co w tym kontekście najistotniejsze, także twórczość translatorska Silberstein wpisuje się w formułę „twórczości niepozornej”, „[...] a więc twórczości niepierwszoplanowej, [...] ubocznej, niekoniecznie wysoko artystycznej [...]" ${ }^{19}$ (Rajewska 2015: 275), a wskutek tego niedocenianej. Autorka Wstępu do estetyki nowoczesnej — inaczej niż naukową twórczość -

mogą oni przyjmować zasady tego rodzaju tłumaczenia, by zwrócić uwagę na istotną rolę kobiet. Omówienie tej kwestii wymaga jednak przyjęcia odrębnej perspektywy.

18 Jak zaznacza Rajewska, twórczość translatorska kobiet profesjonalizuje się w Polsce dopiero w drugiej połowie $\mathrm{XX}$ wieku, co wiązało się również z podniesieniem honorarium.

Przed wojną za tłumaczenia płacono słabo, ale sytuacja zmieniła się po wojnie, wraz z powstaniem wielkich państwowych wydawnictw, rozporządzających znacznie większymi środkami niż dawne firmy wydawnicze [...]. (Rajewska 2015: 285)

19 Korzystam z wyrażenia „twórczości niepozornej” za Ewą Rajewską. Jak jednak podkreśla badaczka, zostało ono ukute przez Jerzego Strzelczyka i następnie zaadaptowane przez Ewę Kraskowską. 
publikowała swoje przekłady pod pseudonimami Ada Silbi i prawdopodobnie Adela $S^{20}$. Ale zachowują one ślady osobowości tłumaczki, jej rozpoznania siebie i swego miejsca w społeczeństwie. Jej przekłady powinny więc być badane „[...] ze względu na to, co mogą nam powiedzieć o ich [kobiet - A.C.] interwencji w kulturowe i intelektualne ruchy ich czasów, oraz o sposobach, w jakie interpretują one swoje płciowe tożsamości jako istotne" (Simon 1996: 40). Przekłady „Ady Silbi” vel „Adeli S.” pozwalają określić rolę, jaką Silberstein przypisywała aktywności tłumaczki, i jaką jej przekłady rzeczywiście odegrały. Istotne wydają się dwie kwestie. Po pierwsze, przedmowa do Kobjety, będąca jedynym komentarzem Silberstein — zarówno do prac Key, jak i podjętych przekładów — jest nie tyle komentarzem do tłumaczenia i interpretacji tekstu, ile próbą umocowania kobiecej podmiotowości i zaznaczenia jej na polu intelektualnym, na którym ówcześnie wciąż marginalizowano autorytet kobiet $^{21}$.

Po drugie, translatorska twórczość badaczki wpisuje się zarazem w konteksty polityczny, społeczny i ekonomiczny. Silberstein, podejmując się przekładu wybranych rozpraw szwedzkiej feministki, opowiada się za rozpoznaniami Key, zgodnie z którymi różnica płciowa nie stoi w opozycji do fallogocentrycznego porządku. Rewolucyjny potencjał postulatów autorki Indywidualności polegał na, powtórzmy, rezygnacji ze znaczeń, które od wieków konstytuowały pojęcia „kobiety” i „mężczyzny”, przy jednoczesnym nieodrzucaniu tych pojęć, lecz przepracowaniu ich tak, by uwzględnienie - koniecznej do prawidłowego funkcjonowania społeczeństwa - różnicy płciowej nie prowadziło do hegemonii i dominowania męskiej reprezentacji, ale do symbolicznej równości kobiety i mężczyzny, której domagały się ówczesne feministki.

Jak zostało już podkreślone, przekład feministyczny nie sprowadza się jedynie do praktyk przekodowania językowego ${ }^{22}$, jest również głosem w sprawach społecznych. Zatrzymajmy się przy tym dłużej. Wydaje się, że celnie wskazuje ona na funkcjonowanie przekładów doko-

20 Nader prawdopodobne jest, że pod takim pseudonimem pierwszego polskiego przekładu Alicés Adventures in Wonderland (Alinki w krainie cudów) Lewisa Carolla dokonała Silberstein. Hipotezę taką stawia Monika Adamczyk-Garbowska. Zdaniem badaczki trop ten potwierdzać może, po pierwsze, publikowanie pod pseudonimem tłumaczeń prac Key. Jak stwierdza, „[...] być może przyjęła [Silberstein - A.C.] inny pseudonim na potrzeby wydania klasycznej pozycji Carolla?’. Po drugie, przekład Alinki... ujawnia wtrącenia z języka niemieckiego, „[...] bardzo dobrze znanego Adeli Silberstein [...]”. Adamczyk-Garbowska nie rozstrzyga, czy Adela S. jest tą samą osobą, która napisała Wstęp do estetyki nowoczesnej. Badaczka zaznacza jedynie, iż wątpliwe jest, by chodziło o Adelę Zylbersztajnową - tłumaczkę poezji angielskiej - sygnującą swoje prace jednak imieniem i nazwiskiem (Adamczyk-Garbowska 2019),

21 Przypomnijmy, że na przełomie XIX i XX wieku Polki nadal nie miały pełnych praw do studiowania, wobec czego Silberstein była skazana na studia za granicą, na Uniwersytecie w Zurychu.

22 Warto przy tym dodać, że w przypadku przekładów, którymi zajęła się Silberstein, należy mówić o ingerencji opierającej się na opatrzeniu tekstu komentarzem tłumacza, nie zaś na językowych interwencjach i uzupetnieniach. Te zresztą trudno byłoby rozpoznać, nie wiadomo bowiem, z jakiego języka ostatecznie badaczka tłumaczyła prace Key. Choć były one pisane w języku szwedzkim, wydawano je także między innymi w języku niemieckim. W przedmowie do Trwonienia sit kobiecych (do wydania z 1898 roku) Key powiada: „książa obecna zawiera treść [...], zestawioną przez moją tłumaczkę i wydaną w niemieckim języku" (Key 1905b: 2). Trudno jednoznacznie stwierdzić, czy w tym czasie również pozostałe rozprawy szwedzkiej działaczki, w tym Kobjetę, Indywidualność i Potrzeby życia, były znane niemieckim czytelnikom. Niemniej jest bardziej niż prawdopodobne, że właśnie z niemieckiego Silberstein je tłumaczyła, choć pewności ze względu na skąpą wiedzę o jej biografii mieć nie można. 
nanych przez Silberstein, wykorzystywanych w prasie kobiecej ${ }^{23}$ na początku XX wieku. Jak pisze Jerzy Franke:

Czasopisma kobiece początku XX wieku przejmują część funkcji, które pełniły dotychczas nieformalne instytucje życia towarzyskiego. Jedne $\mathrm{z}$ nich zamierają, drugie w nowych warunkach spełniać poczynają inną rolę. [...] Część funkcji dawnych salonów przejmują czasopisma, część natomiast stowarzyszenia kobiece. [...] Czasopisma wspierają cele stowarzyszeń, najważniejsze stowarzyszenia prowadzą działalność wydawniczą. Opisana wyżej sytuacja powoduje znaczne zmiany na kobiecym rynku czasopiśmienniczym. Zróżnicowaniu programów towarzyszy zmiana środków ekspresji treści wydawniczych. (Franke 2000: 40)

Działania podejmowane w czasopismach (trzeba wymienić tu m.in. „Ster”, „Na Posterunku” ${ }^{44}$, a także działający z nich najwcześniej „Bluszcz” ${ }^{25}$ ) zmierzały do ukształtowania pożądanych postaw społecznych względem emancypacji kobiet. Choć w periodykach dominowała myśl o konieczności równouprawnienia kobiet i mężczyzn ${ }^{26}$, inne poglądy nie były marginalizowane; pisma umożliwiały ich wymianę, stwarzając przestrzeń dla polemik osób (głównie kobiet) zaangażowanych w realizację jakkolwiek pomyślanych postulatów emancypacji.

Mimo że na łamach wymienionych czasopism niejednokrotnie wspomina się o samej Key ${ }^{27}$, próżno szukać w nich cytatów i odniesień do prac działaczki (wyjątek stanowią poje-

23 Mówiąc o prasie kobiecej tego okresu, korzystam z definicji Jerzego Franke. Przyjął on definicję prasy kobiecej jako tej grupy periodyków, które „[...] adresowane są przede wszystkim lub wyłącznie do kobiet”. Jak czytamy dalej:

Wydaje się, iż tylko taka, mocno tautologiczna definicja, umożliwia identyfikację prasy kobiecej, niezależnie od jej zawartości. Jakakolwiek bowiem próba typologii pism tej grupy, dokonywana z punktu widzenia zawartości pism, typowych działów czy dominującej problematyki jedynie pozornie stanowi klucz klasyfikacyjny. Te „typowe” materiały w postaci działu mód czy porad domowych, problematyki małżeństwa, rodziny czy sytuacji społecznej kobiet pojawiały się w większości tytułów, ale nie we wszystkich. Wskazać można na szereg ważnych pism, które programowo („Ster”, pisma patronackie — w przypadku mód) bądź w wyniku okoliczności historycznych („Na Posterunku”) uniknęły owej „typowej” zawartości. (Franke 1999: 9)

Silberstein należała do współpracowników „Na Posterunku” - tygodnika kobiecego poświęconego sprawom społecznym, ekonomicznym i politycznym, powstałego pod kierunkiem literackim Zofii Daszyńskiej-Golińskiej. Periodyk służył rozpowszechnianiu głosu kobiet; poruszano w nim problemy ich statusu ekonomicznego, wykształcenia, pracy zawodowej, społecznych obowiązków oraz pozycji, jaką powinny zająć w tworzącym się wówczas państwie polskim (Ciechomska 2019).

25 „Otwarta, dialogowa formuła »Bluszczu « określiła akcenty programowe. Redakcja unikała radykalnych haseł, co nie znaczy, iż odrzuca postulaty emancypacyjne. Pismo eksponowało jednak te elementy, które wspólne były większości odłamów ruchu kobiecego. Redakcja opowiadała się za różnorodnym, wielokierunkowym rozwojem ruchu kobiecego. Przeciwstawiano się nierealnym, jeśli zważyć na zróżnicowanie programowe organizacji i stowarzyszeń, próbom zjednoczenia ruchu kobiecego” (Franke 1999: 65-66). „[...] rozwinąt »Bluszcz « $\mathrm{w}$ tym okresie $\mathrm{w}$ najpełniejszej formie program równouprawnienia kobiet. Pozbawiony doktrynerskich obciążeń (od których nie był wolny warszawski »Ster «) i programowych uprzedzeń dopuszczał się ścieranie odmiennych głosów i poglądów, nie porzucając wszak raz obranej drogi” (Franke 1999: 205).

Powracającym hasłem w kolejnych numerach „Steru” jest wyrażenie „bez różnicy płci”. Czasopismo zajmowało: „[...] wyjątkową pozycję pośród pism kobiecych w Królestwie. Był jedynym periodykiem feministycznym, w całości poświęconym idei pełnej, w tym politycznej, emancypacji kobiet. Pośród pism kobiecych reprezentował program najbardziej radykalnych reform społecznych" (Franke 1999: 102).

Przykładem tego jest chociażby informacja o przemówieniu Key na wiecu sufrażystek w Szwecji. („Ster” 1910: 347). Warto przy tym dodać, że w jednym z numerów „Steru” pojawia się także informacja o wydaniu Wstępu do estetyki nowoczesnej Silberstein. Co ważne, w periodyku zamieszczano informacje jedynie o publikacjach 
dyncze przytoczenia ze Stulecia dziecka). Można natomiast odnaleźć ślady ich wykorzystania w numerach wydanych po 1903 roku $^{28}$. Świadczy o tym chociażby następujący fragment artykułu o wychowaniu:

Dlatego to właśnie wychowaniem powinna się trudnić matka, której niezbadany macierzyński instynkt serca podaje często cudowne podszepty i nieomylne wskazówki, kobieta wogóle, jako głębszem obdarzona uczuciem i łatwiej umiejąca przemawiać do serca. („Bluszcz” 1904: 458)

Powyższy cytat wskazuje nie tylko na znajomość myśli Key, dotyczącej kwestii macierzyństwa - o której traktują poprzednie części rozdziału — ale również na wykorzystywanie jej przez niektóre z ówczesnych feministek do własnych refleksji. Przykładem jest wypowiedź Zofii Seidlerowej ${ }^{29}$ :

[...] macierzyństwo, do którego natura przeznaczyła kobietę, przestało być jedynym jej powołaniem, [...] zakreślać jednak będzie wiecznie różnice pomiędzy nią a mężczyzną. Rozumie się, że tam, gdzie się wznosi gmach nowy, stary upaść musi, ale kobiety budować powinny nowe ideały na fundamentach starego gmachu, bo te są wiecznie trwałe. Powinny rozwijać w sobie do granic możliwej doskonałości wszystkie skarby, jakiemi obdarzyła je natura, co nie staje bynajmniej na przeszkodzie w zdobywaniu coraz nowych placówek działania, nie osłabia niezawisłości i samodzielnego, indywidualnego bytu, nie broni przed wyrobieniem własnych zapatrywań i pojęć. (Seidlerowa 1904: 399)

autorów współpracujących z redakcją „Steru” (jednak żadne źródła nie potwierdzają współpracy Silberstein z czasopismem) lub istotnie zaangażowanych w kwestię ruchu kobiecego („Ster” 1912; 10).

28 Przypomnijmy, co istotne z tego punktu widzenia, że dokonane przez Silberstein przekłady prac Key zostały wydane kolejno w latach: 1903, 1904, 1907. Z kolei:

lata 1905-1914 są szczególnym okresem w historii polskiej prasy kobiecej. Okresem w miarę swobodnego rozwoju czasopiśmiennictwa, mniej skrępowanej niż w latach poprzednich możliwości wyrażania poglądów redakcji. Od końca 1905 r. zmieniają się zasady funkcjonowania prasy. Manifest carski z 30.10.1905 r. (zwany konstytucyjnym) proklamował m.in. wolność słowa i prasy. W związku z tym, choć nie bez prób przeciwdziałania ze strony urzędów cenzury, które uważały, że do czasu uchwalenia nowego prawa prasowego obowiązują dotychczasowe przepisy cenzuralne, od 7 listopada większość czasopism warszawskich zaczęła ukazywać się bez ingerencji cenzury. (Franke 1999: 29)

29 Należy w tym miejscu powiedzieć, że dwa lata później Seidlerowa skrytykowała poglądy Key (zob. przypis 4). Zdaniem polskiej działaczki autorka Trwonienia sit kobiecych promowała niebezpieczny nurt ruchu kobiecego, który określany był „wolną miłością i macierzyństwem bez małżeństwa” (Seidlerowa 1906: 2). Stanowisko Seidlerowej komentuje Renata Bednarz-Grzybek:

Kobieta, która nie uznaje roli ojca w wychowaniu dziecka, nie warta jest być matką. W tym przypadku nie chodzi wyłącznie o jej własne, macierzyńskie szczęście, lecz o dobro dziecka. Odsunięcie od niego drugiego rodzica jest egoistyczne i krzywdzące. Seidlerowa uświadamiała społeczeństwo co do sfery wspólnych rodzicielskich obowiązków względem dziecka, umacniania się wzajemnego w obowiązkach, a nie ich osłabiania. (Bednarz-Grzybek 2015: 167)

Jak pisałam wcześniej, krytykowanie Key — zarówno przez Seidlerową, jak i inne feministki — wynikało z niedostatecznego zrozumienia myśli szwedzkiej autorki i tym samym niewłaściwego interpretowania jej założeń. Niemniej poglądy Seidlerowej w znacznej mierze okazują się zgodne ze stwierdzeniami Key. 
Jak wynika z przytoczonej wypowiedzi, działaczka dostrzega zgodną z założeniami Key potrzebę podkreślania różnicy płciowej ${ }^{30}$, o której zniesienie walczyły wówczas kobiety, oraz potrzebę ekspresji kobiecej natury poprzez macierzyństwo. Podobnie wypowiadano się na tamach „Steru” i „Na Posterunku”:

Ze wszystkich tych oznak widać, że społeczeństwo coraz lepiej pojmuje, jak nieodpowiedni i niewystarczający jest obecny układ społeczny, w którym rodzina ekonomicznie i prawnie opartą jest na mężczyźnie, wbrew naturalnemu stanowi rzeczy, gdyż podstawy uczuciowe bytu rodzinnego tkwią w matce. (Kodisowa 1909: 167)

Są obowiązki, które nie mogą być zaniechane, [...] do nich należy ochrona dziecka i doprowadzenie dzieciństwa do najpełniejszego i najdoskonalszego rozkwitu. [...] Tę służbę podniosłą, wymagającą poświęcenia życia całego i podporządkowania siebie, podejmują kobiety najchętniej, bo miłość do dziecka jest przyrodzoną sferą ich uczuć, a więc ich wolą i powołaniem [...]. (Gerżabkowa 1917: 3)

Na łamach periodyków podkreślano zatem znaczenie macierzyństwa także jako funkcji społecznej i podzielano tym samym stanowisko szwedzkiej działaczki, choć nie przywoływano jej po imieniu.

Postawioną tezę wspierają również poniższe słowa anonimowego autora (podpisanego jedynie inicjałami M.Chr.), które zamieszczono w jednym z numerów „Steru”:

Pierwszym więc warunkiem szczęścia małżeńskiego jest wzajemna miłość małżonków, jako jedyny i pewny probierz ich doboru wzajemnego. [...] a dzieci z takich par zrodzone [wychowanie A.C.] może uczynić ludźmi, możliwie najharmonijniej rozwiniętymi fizycznie i moralnie [...]. Zadaniem wychowania bowiem jest dać dziecku warunki jak najlepszego rozwoju jego sił i indywidualności [...]. (M.Chr 1912: 8-9)

W ten sposób wyrażony zostaje jednoznacznie pozytywny stosunek wobec poglądów Key co istotne, także w pismach udostępnionych polskim czytelniczkom i czytelnikom przez Silberstein - propagujących idee porzucenia działań zmierzających do zrównania kobiet i mężczyzn oraz dowartościowania różnicy płciowej, a także konieczności przepracowania instytucjonalnego modelu małżeństwa oraz współpracy kobiet i mężczyzn w wychowywaniu dzieci, stanowiącej warunek harmonijnego funkcjonowania zbiorowości.

Przypuszczenie o cyrkulowaniu pism Key w przekładach Silberstein wśród ówczesnych emancypantek zyskuje na prawdopodobieństwie, jeśli wziąć pod uwagę język, którym posługiwano się w przywoływanych czasopismach. Oprócz powracającej w licznych wypowiedziach zgodności światopoglądowej z myślą autorki Stulecia dziecka zauważyć można także przeniesienie z jej prac - czyli z przekładów Silberstein — określonych wyrażeń. Na zasadność tego tropu wskazuje między innymi przejęcie z pism Key określenia filantropii jako „zapalenia kadzidła przy otworze kloaki”31. Kolejny przykład stanowi następujące zdanie: „Indywidualność jednostki, przejawiająca się w indywidualnym powołaniu,

30 O podkreślaniu różnicy płciowej pisano także w „Na Posterunku”:

Nie o równość chodzi jednak, lecz właśnie o inszość. Kobieta i mężczyzna, różni fizycznie, wnoszą tak odmienne wartości kulturalne do cywilizacyi. (Daszyńska-Golińska 1917: 1)

31 W numerze tym wspomina się o Key w artykule dotyczącym wiecu z 12 kwietnia, na którym jedna z referentek, zdaniem redakcji czasopisma: 
może się uwydatnić w całej pełni tylko na tle wszechstronnego ro z wi n i ę c i a je d n o s t ki” (podkreślenia - A.C.; Kurnatowski 1907: 224). To mocne przekonanie koresponduje z omawianymi w poprzednich częściach rozdziału założeniami Key, dotyczącymi prawa każdej jednostki do indywidualnej ekspresji i jej uwarunkowań.

Co jednak ważniejsze, przytoczone słowa potwierdzają ciągłość między poglądami ówczesnych feministek a udostępnioną przez Silberstein myślą Key. Przejawia się ona w samym nacechowaniu języka ich wypowiedzi. W artykułach zamieszczonych w numerach po 1903 roku operuje się bowiem wyrażeniami, które można znaleźć w polskich wersjach rozpraw szwedzkiej autorki, głównie w Indywidualności. Przykładem następujące zdania: „[...] musi nadejść kierunek in d y w i d u a li z u ją c y i to, co jest z nim związane z natury rzeczy" (Kodisowa 1909: 163); „Jednostka zdolna brać wybitny udział w jednym [...], jest jednostką czołową, zarówno najsilniej odczuwającą swoje in dy widualn e » ja «, jak i najwięcej dodatnio oddziaływującą na ogólny rozwój społeczeństwa” (Kurnatowski 1907: 225); „Czyn — to ruch, to wysiłek podjęty dla urzeczywistnienia drzemiących w duszy człowieka pragnień [...]. Jest w czynie piękno, jest wyzwolenie wewnętrznych, utajonych w nas potęg, jest oddanie w służbę społeczeństwa in dywidualnych sił i wolności” ${ }^{32}$ (podkreślenia - A.C.; Witkowska 1917: 1-2). Figury ,jednostki”, „indywiduum”, „sił”, „czynu” i „utajonych w nas potęg” należały oczywiście do podstawowych ideologemów epoki. Nie sposób nie sytuować ich w kontekście pism Maxa Stirnera, Karla Marksa, Friedricha Nietzschego czy Stanisława Brzozowskiego. Do języka Key oraz autorek(-rów) wspomnianych artykułów mogły więc wejść właśnie za sprawą filozoficznych lektur. Niemniej nie sposób nie zauważyć, że ich uprzedniość w polskojęzycznym dyskursie feministycznym jest powiązana z tłumaczeniami Silberstein. Na łamach „Steru” i „Na Posterunku” brak wcześniej podobnych wyrażeń.

Przeanalizowanie wybranych periodyków z początku XX wieku potwierdza zatem zakładany wpływ zarówno poglądów Key, jak i, co ważniejsze, przekładów Silberstein, w których jedynie były powszechniej dostępne, na światopogląd ówczesnych feministek, a co za tym idzie - na funkcjonowanie tłumaczenia w społeczeństwie i kulturze. Nie tylko koncepcje wysunięte przez szwedzką działaczkę znalazły odzwierciedlenie w wypowiedziach zamieszczanych na łamach prasy kobiecej; tłumaczenia dokonane przez autorkę Wstępu do estetyki nowoczesnej dostarczały emancypantkom języka do mówienia o ówczesnych problemach. Stanowiły więc dla działaczek problemowe i pojęciowe, a przede wszystkim językowo-terminologiczne zaplecze, do którego prawdopodobnie sięgały, wypracowując własne przekonania.

[...] nie wyróżniła dostatecznie pojęcia filantropji, (o której słusznie powiada Ellen Key, że jest lampką zapaloną u wejścia do kloaki) od pojęcia twórczej pracy socjalnej. („Ster” 1907: 108)

Działaczki odrzucały stosowane wówczas akcje o charakterze filantropijnym, uznając je za nieskuteczne.

Szwedzka autorka pisze z kolei:

Z punktu widzenia samych kobiet, dzieci, mężów, a wreszcie wytwórczości ogólnej trzeba domagać się jasnego uświadomienia faktu, że społeczeństwo musi wybrać jedno z dwojga: albo zmienić warunki pracy kobiet, albo też zdecydować się na stopniowe rozprzężenie rodziny; albo musi ono przekształcić stosunki zarobkowe wszystkich, albo przygotować się na zwyrodnienie ogólne. Wszelka filantropia — a nigdy nie było jej tyle co teraz — jest tylko zapalaniem kadzidła przy otworze kloaki. Kadzidło czyni powietrze znośniejszym dla przechodniów, lecz nie zapobiega szkodliwemu działaniu kloacznych wyziewów. (Key 1928: 27)

Na korzystanie z przytaczanego określenia Key przez wspólpracowniczki „Steru” uwagę zwraca także Jerzy Franke (1999: 29).

32 „Każdy czyn nie-wolny, nie-indywidualny, jaki popełnia człowiek indywidualnie rozwinięty, dręczy go [...]. Tylko czyny zgodne z jego własną treścią mogą szczęściem go obdarzyć” — powiada Key (1904: 22). 
Implikacje przekładów, kumulujące się w ich przyswojeniu przez odbiorcę i zastosowaniu w danym kontekście społecznym i kulturowym, wyznaczają tłumaczki, których działanie jest aktywnym czynnikiem w procesie komunikacji kulturowej ${ }^{33}$. Przeprowadzona z tej perspektywy analiza sposobów korzystania przez polskie feministki z założeń Key - w tym, podkreślmy, głównie z dostarczonych przez Silberstein spolonizowanych sformułowań szwedzkiej autorki - posłużyło do wydobycia kwestii, których nie ujawnia aktywność naukowa autorki Wstępu do estetyki nowoczesnej, a które wyłaniają się z jej działalności translatorskiej. Działalność ta z dwóch powodów stanowi istotny wkład w kulturę. Po pierwsze, ze względu na wykorzystanie okazji, jaką stwarzała praca tłumaczki, dyskursu tłumacza do zabrania głosu w społeczeństwie i do opowiedzenia się za określonymi poglądami na emancypację kobiet. Po drugie - ze względu na to, że z języka feministycznego zaproponowanego przez Silberstein czerpały ówczesne działaczki. Rekonstrukcja tych kwestii i wysnute z niej wnioski pozwalają ją uznać za kobietę-myślicielkę, zaangażowaną również w sprawy zmiany społecznej świadomości.

\section{Bibliografia}

Adamczyk-Garbowska Monika (2019), Adela S(ilberstein)? Zagadkowa tożsamość autorki pierwszego polskiego przektadu „Alice's Adventures in Wonderland” Lewisa Carrolla, „Teksty Drugie", nr 4.

Barad Karen (2007), Meeting the universe halfway: Quantum physics and the entanglement of matter and meaning, Duke University Press Books, Durham.

- (2012), Posthumanistyczna performatywność. Ku zrozumieniu, jak materia zaczyna mieć znaczenie, przeł. J. Bednarek [w:] Teorie wywrotowe. Antologia przektadów, red. Gajewska A., Wydawnictwo Poznańskie, Poznań.

Bednarz-Grzybek Renata (2015), Zofia Seidlerowa (1859-1919) i „kwestia kobieca” na tamach „Bluszczu”, „Lubelski Rocznik Pedagogiczny”, z. 1.

„Bluszcz” (1904), nr 39.

Borkowska Grażyna (1996), Cudzoziemki. Studia o polskiej prozie kobiecej, IBL, Warszawa.

Butler Judith (2008), Uwiktani w pteć. Feminizm i polityka tożsamości, przeł. K. Krasuska, Wydawnictwo Krytyki Politycznej, Warszawa.

Chałupnik Agata (2004), Sztandar ze spódnicy, Wydawnictwo Errata, Warszawa.

33 Z tego względu należy podkreślić, że nie można postrzegać Key wyłącznie jako myślicielki skupionej wokół problemów podmiotowości, tożsamości i płciowości, ale także jako interpretatorkę politycznych, społecznych i kulturowych sfer życia. 
Ciechomska Aleksandra (2019), Kwestia przedmiotu estetycznego a obiektywność badań estetycznych. Estetyka Ady Silberstein, „Zagadnienia Rodzajów Literackich”, z. 1.

Cixous Hélène (1993), Śmiech Meduzy, przeł. A. Nasiłowska, „Teksty Drugie”, nr. 4/5/6.

Daszyńska-Golińska Zofia (1917), Kobiety we wspótczesnem życiu publicznem, „Na Posterunku", nr 20.

De Beauvoir Simone (1972), Druga pteć, przeł. G. Mycielska, M. Leśniewska, t. 1 i 2, Wydawnictwo Literackie, Kraków.

Duda Maciej (2017), Emancypanci emancypatorzy. Mężczyźni wspierajacy emancypację Polek $w$ drugiej potowie XIX i na poczatku XX wieku, Wydawnictwo Naukowe Uniwersytetu Szczecińskiego, Szczecin.

Franke Jerzy (1999), Polska prasa kobieca w latach 1820-1918. W kregu ofiary i poświęcenia, Stowarzyszenie Bibliotekarzy Polskich, Warszawa.

- (2000), Wokót buntu i pokory. Warszawskie czasopisma kobiece w latach 1905-1918, Stowarzyszenie Bibliotekarzy Polskich, Warszawa.

Fuss Diana (1989), Essentially Speaking: Feminism, Nature and Difference, Routledge, New York.

Gerżabkowa Maria (1917), Z mitości dla dziecka, „Na Posterunku”, nr 5.

Górnicka-Borantyńska Aneta (2018), Stańmy się sobą. Cztery projekty emancypacji (18631939), Wydawnictwo Czarna Owca, Warszawa.

Jahołowska-Koszutska Ludwika (1907), Herezje w ruchu kobiecym, Księgarnia Powszechna, Warszawa.

Key Ellen (1903), Kobjeta, przeł. i wstęp A. Silberstein, Wydawnictwo Władysława Okręta, Warszawa.

— (1904), Indywidualność, przeł. i wstęp A. Silberstein, Księgarnia E. Wende i Spółka, Warszawa.

- (1905a), Nowe szkice, przeł. B. Neufeldówna, Wydawnictwo Gebethnera i Wolffa, Warszawa.

- (1905b), Trwonienie sit kobiecych, przeł. I. Moszczeńska, Wydawnictwo Księgarni Naukowej, Warszawa.

- (1905c), Mitość i matżeństwo, przeł. W. Witwicki, Księgarnia Bernarda Połonieckiego, Warszawa.

- (1907), Potrzeby życia, przeł. A. Silbi, Księgarnia E. Wende i Spółka, Warszawa.

- (1928), Stulecie dziecka, przeł. I. Moszczeńska, „Nasza Księgarnia”, Warszawa.

Kodisowa Józefa (1909), Kwestja rodziny. W sprawie kobiecej, „Ster”, nr 5.

Kraskowska Ewa (2015), Czy jest możliwa (i potrzebna) herstoria literatury polskiej? [w:] Widnokregi literatury - wielogtosy krytyki. Prace ofiarowane profesor Teresie Walas, Wyd. UJ, Kraków.

Kristeva Julia (1981), Women's Time, „Signs”, nr 1, przeł. A. Jardine, H. Blake.

Kuczalska-Reinschmit Paulina (1903), Z historyi ruchu kobiecego [w:] Gtos kobiet w kwestyi kobiecej, red. M. Wiśniewska, Stowarzyszenie Pomocy Naukowej dla Kobiet J.I. Kraszewskiego, Kraków.

Kurnatowski Jerzy (1907), Jednostka w zrzeszeniu, „Ster”, nr 6.

M.Chr (1912), O warunkach szczéścia w matżeństwie, „Ster”, nr. 13-14.

Nałkowska Zofia (1906), Kobiety, Wydawnictwo Gebethnera i Wolffa, Warszawa.

Robinson Douglas (1995), Theorizing Translation in a Woman's Voice: Subverting the Rhetoric of Patronage, Courtly Love and Morality, „The Translator”, no. 1-2. 
Rajewska Ewa (2015), Twórczość przektadowa kobiet [w:] Polskie pisarstwo kobiet w wieku XX: procesy i gatunki, sytuacje i tematy, red. Kraskowska E., Kaniewska B., Wydawnictwo Naukowe UAM, Poznań.

Schopenhauer Arthur (2009a), Świat jako woli drugie rozważanie [w:] tegoż, Świat jako wola i przedstawienie, t. I, przeł. J. Garewicz, Wydawnictwo Naukowe PWN, Warszawa.

- (2009b), Świat jako woli drugie rozważanie [w:] tegoż, Świat jako wola i przedstawienie, t. II, przeł. J. Garewicz, Wydawnictwo Naukowe PWN, Warszawa.

Seidlerowa Zofia (1904), „Bluszcz”, nr 34 (publikacja niezatytułowana).

- (1906), Kraina dzieci naszych, „Bluszcz”, nr 1.

Silberstein Ada (1902a), Leibniz’ Apriorismus im Verhältnis zu seiner Metaphysik, R. Wagner Sohn, Zürich.

- (1902b), Studja nad Leibnizem, „Przegląd Filozoficzny”, z. 3.

- (1904), Leibnizes Apriorismus im Verhältnis zu seiner Metaphysik, Mayer, Berlin.

- (1908), Wspótczesna estetyka eksperymentalna, „Przegląd Filozoficzny”, z. 4.

Simon Sherry (1996), Gender in Translation, Routledge, Londyn-Nowy Jork.

„Ster” (1907), nr 3.

- (1910), nr. 9-10.

- (1912), nr 3.

Szopa Katarzyna (2017), „Nieziszczone narodziny”. Cixous i Irigaray, czyli kobiety z Czarnego Kontynentu, „Postcriptum Polonistyczne”, nr 2.

- (2018), Poetyka rozkwitania. Różnica ptciowa w filozofi Luce Irigaray, Wydawnictwo IBL PAN, Warszawa.

Van Dolphijn Rick, Van der Tuin Iris (2018), Wywiad z Karen Barad, przeł. J. Czajka [w:] tychże, Nowy materializm. Wywiady i kartografie, przeł. J. Czajka, A. Handke, J. Maliński, A. Marcisz, C. Rudnicki, T. Wiśniewski, Fundacja Machina Myśli, Gdańsk-Poznań-Warszawa. Von Flotow Luise (1997), Translation and Gender: Translating in the "Era of Feminism”, University of Ottawa Press, Ottawa.

Werner-Silberstein Ada (1911), Wstęp do estetyki nowoczesnej, Bibljoteka Estetyczna, Księgarnia E. Wende i Spółka, Warszawa.

Widzenie bliskie i dalekie (1957), red. Breza T., Nałkowska Z., Czytelnik, Warszawa.

Witkowska Helena (1917), Czy nadaremnie?, „Na Posterunku”, nr 39.

Wspótczesne teorie przektadu. Antologia (2009), red. Bukowski P., Heydel M., Wydawnictwo Znak, Kraków.

Żółkiewski Stefan (1973), Spoteczny obieg literatury [w:] tegoż, Kultura literacka (1918-1932), Zakład Narodowy im. Ossolińskich, Wrocław. 